\title{
FACTORS INFLUENCING MOTIVATION OF SALES STAFF ACROSS SELECTED ORGANIZED RETAIL FORMATS IN TIER 1, 2 AND 3 CITIES IN KARNATAKA
}

\author{
*Shyam B R **Dr N K Ramachandra Gowda
}

\section{Introduction}

Today's retail sector is facing a challenge of managing its sales staff and high attrition fever has become a critical and significant issue. The demand for motivating employees to perform well and achieve goals is the constant challenge of every retail managers. This paper will be just a small effort to get into the depth of one aspect of motivation in the ocean of human resource development.

The purpose of this study was to identify which factors have the most influence on motivation of sales staff across selected organized retail formats in tier 1,2 and 3 cities in Karnataka and to see how it can attract, retain and develop quality sales staff in achieving their selling success. Specific hypothesis which this study sought to answer are: (1) There were no significant differences between gender, marital status, age, educational background, experiences, employment types and incomes contributing to sales staff motivation across tiers. (2) Motivation factors were not having influence and significant difference on sales staff across formats.

\section{Background of the Study}

The Site: This research was set in a selected organized retail formats in Karnataka that consisted of all the full time permanent, part time permanent, part time/casual and trainees of tier 1, 2 and 3 cities: that is $40 \%$ from tier 1, 40\% from tier 2 and $20 \%$ from tier 3 cities.

Case Methodology and Sample Design: To achieve desired representation from the various organized retail formats and cities, convenience and stratified random sampling were selected.

Key Words: Motivation, sales staff, organized retail formats, convenience sampling, stratified sampling, motivation variables, independent and dependent variables

Convenience sampling technique has been used while selecting the selected organized retail formats for responses. Stratified sampling technique has been used for collecting data from the sales staff of tier 1, 2 and 3 cities in Karnataka. A self administered structured questionnaire is constructed and kept same to collect information from sales staff of selected organized retail formats from tier 1, 2 and 3 cities in Karnataka and the questionnaire consists two sections: Part A: Demographic

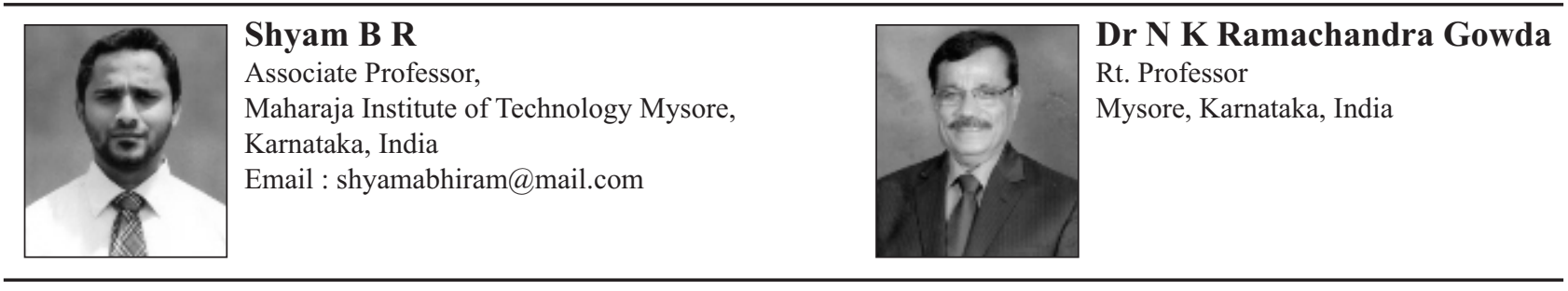


information and Part B: Job motivation related information. Other field visits to the procurement centers, retail outlets and personal interview is also used to collect data and information. The observation method has been used in few cases to cross check the information collected through other methods.

\begin{tabular}{|l|l|}
\hline \multicolumn{2}{|c|}{ Table 1.1: Sample Design } \\
\hline Sample Unit & Sales staff of organized retail formats \\
\hline Sample Size & 500 \\
\hline Sample Method & Convenience, stratified random and simple random sampling \\
\hline Sample Population & Sales staff of organized retail formats \\
\hline Sampling Data & Primary field, survey data \\
\hline Sample Area & Tier 1, tier 2, and tier 3 cities in Karnataka \\
\hline Survey Method & Questionnaire - Likert's 7 point scale \\
\hline Data Analysis Method & $\begin{array}{l}\text { Descriptive statistics, t-test, stepwise multiple regression, correlation and one way } \\
\text { ANOVA technique }\end{array}$ \\
\hline Variable Selected & $\begin{array}{l}\text { Dependent variables: Selected Organized Retail Formats } \\
\text { Independent variables: Motivation factors which are kept constant }\end{array}$ \\
\hline $\begin{array}{l}\text { Pay/Compensation Benefits Motivation (pcbm), Job Security Motivation (jsm), Team/Social/Interper sonal } \\
\text { Motivation (tsim), Supervisory Motivation (sm), Career/Growth Motivation (cgm), Skill Set and Competency } \\
\text { Motivation (sscm), Welfare and Recreational Facility Motivation (wrfm), Recognition and Reward (rr), } \\
\text { Working Condition/Environment Motivation (wc em), Communication/Company Policy and Administration } \\
\text { Motivation (ccpam), Worker's Participation in Management (wpm) and Organizational Commitment (oc). }\end{array}$ \\
\hline
\end{tabular}

Presentation of the Data: The primary data collected was edited, coded, classified and tabulated into analyzed information by using SPSS version 16.0. The information was in frequency distribution and percentage tables and bar graphs. Much of the information needed to be based on the number of years each sales staff had worked in formats. $15.2 \%$ of the respondents had worked at formats between 012 months, $36 \%$ between $1-2$ years, $40 \%$ between $2-4$ years, $8.4 \%$ between $4-10$ years and $0.4 \%$ between 11 or more years. This implied that the majority of respondents had worked between 2-4 years and 1-3 years. This was necessary because there was restructuring that took place and necessitated a need of motivation for organized retail formats that was able to meet the challenges of the 21 st century.

\section{Summary of Survey Findings}

According to the hypothesis testing presented and discussed the research findings could be summarized as the subsequent points:
1. The researcher noted that most of the respondents were males, unmarried, 18-25 years age groups, degree qualification, 2-4 years of experience, full time permanent and $8000-15,000$ rs monthly salary had been in tier 1, 2 and 3 cities in Karnataka.

2. The response to the research hypothesis 1 indicate that personal factors have significant difference between genders, marital status, age, educational background, experiences, employment types and incomes contributing to sales staff motivations across tiers. Table 1.2 shows the result of paired t-test and one way ANOVA of perceptual difference of sales staff based on personal factors across tier 1, 2 and 3 cities.

- The results of paired t-test of perceptual difference of sales staff gender wise towards motivational factors across tiers has significant difference in the opinions towards the variables like cgm, sscm, wrfm, wcem and wpm. 
- The results of paired t-test of perceptual difference of sales staff marital wise towards motivational factors across tiers have significant difference in the opinions towards the variables like sm, cgm and rr.

- The results of one way anova of perceptual difference of sales staff age wise towards motivational factors across tiers has significant difference in the opinions towards the variables like tsim, sm, cgm, wrfm, wpm and oc.

- The results of one way anova of perceptual difference of sales staff education wise towards motivational factors across tiers has significant difference in the opinions towards the variables like sscm, wrfm, rr, ccpam, wpm and oc.

- The results of one way anova of perceptual difference of sales staff experience wise towards motivational factors across tiers has significant difference in the opinions towards the variables like pcbm and wpm.

- The results of one way anova of perceptual difference of sales staff employment wise towards motivational factors across tiers has significant difference in the opinions towards the variables like pcbm, jsm, tsim, sm, cgm, wrfm, rr and wpm.

- The results of one way anova of perceptual difference of sales staff income wise towards motivational factors across tiers has significant difference in the opinions towards the variables like pcbm, jsm, tsim, sm, cgm, sscm, wrfm, rr, ccpam, wpm and oc.

3. The results of fundamental descriptive statistics (Table 1.3), is evident that sales staffs have significant difference across the formats and factors association with motivation. This means that, formats of tier cities of sales staff have different opinions towards motivation factors across the formats. Also, formats of tier cities of sales staff have significant difference in opinions towards the factors like pcbm, jsm, tsim, sm, cgm, sscm, wrfm, rr, wcem, ccpam, wpm and oc.

- PCBM: One way anova reveals significant difference in PCBM between respondents belonging to different formats, where ' $\mathrm{f}$ ' value of 2.74 is found to be significant at .004 level. The mean score for respondents belonging to hypermarket, supermarket, shopping mall, discount world, departmental store, specialty chain, convenience store, branded outlet, category killer and e-tailing were 73.21, 78.36, 70.21, 77.71, 77.00, 70.64, 74.43, $76.78,72.93$ and 80.57 respectively. Further, means with different superscripts are significantly different from each other as indicated by scheffe post hoc test $(\alpha=0.5)$. Scheffe post hoc test revealed that respondents belonging to e-tailing had highest motivation and respondents belonging to shopping mall and specialty chain were least and respondents belonging to hypermarket, supermarket, discount world, departmental store, convenience store, branded outlet and category killer were inbetween.

- JSM: One way anova reveals significant difference in JSM between respondents belonging to different formats, where ' $\mathrm{f}$ ' value of 2.85 is found to be significant at .003 level. The mean score for respondents belonging to hypermarket, supermarket, shopping mall, discount world, departmental store, specialty chain, convenience store, branded outlet, 
category killer and e-tailing were 73.90 , 74.95, 68.48, 76.00, 78.95, 69.90, 79.90, $72.95,71.14$ and 74.28 respectively. Further, means with different superscripts are significantly different from each other as indicated by scheffe post hoc test $(\alpha=0.5)$. Scheffe post hoc test revealed that respondents belonging to convenience store had highest motivation and respondents belonging to shopping mall and specialty chain were least and respondents belonging to hypermarket, supermarket, discount world, departmental store, branded outlet, category killer and e-tailing were inbetween.

- TSIM: One way anova reveals significant difference in TSIM between respondents belonging to different formats, where ' $\mathrm{f}$ ' value of 3.68 is found to be significant at .000 level. The mean score for respondents belonging to hypermarket, supermarket, shopping mall, discount world, departmental store, specialty chain, convenience store, branded outlet, category killer and e-tailing were 89.31, $85.20,82.34,78.74,83.71,88.69,86.17$, $82.34,85.31$ and 85.60 respectively. Further, means with different superscripts are significantly different from each other as indicated by scheffe post hoc test $(\alpha=0.5)$. Scheffe post hoc test revealed that respondents belonging to hypermarket had highest motivation and respondents belonging to discount world and specialty chain were least and respondents belonging to supermarket, departmental store, shopping mall, convenience store, branded outlet, category killer and etailing were inbetween.

- SM: One way anova reveals significant difference in SM between respondents belonging to different formats, where ' $\mathrm{f}$ ' value of 3.43 is found to be significant at .000 level. The mean score for respondents belonging to hypermarket, supermarket, shopping mall, discount world, departmental store, specialty chain, convenience store, branded outlet, category killer and e-tailing were 88.57, 86.71, 78.00, 78.57, 85.86, 81.93, 81.21, $82.71,81.64$ and 84.71 respectively. Further, means with different superscripts are significantly different from each other as indicated by scheffe post hoc test $(\alpha=0.5)$. Scheffe post hoc test revealed that respondents belonging to hypermarket had highest motivation and respondents belonging to shopping mall and discount world were least and respondents belonging to supermarket, departmental store, convenience store, specialty chain, branded outlet, category killer and etailing were inbetween.

- CGM: One way anova reveals significant difference in CGM between respondents belonging to different formats, where ' $\mathrm{f}$ ' value of 2.52 is found to be significant at .008 level. The mean score for respondents belonging to hypermarket, supermarket, shopping mall, discount world, departmental store, specialty chain, convenience store, branded outlet, category killer and e-tailing were 77.79, 81.00, 70.14, 75.86, 77.79, 71.29, 75.57, $76.64,76.43$ and 77.71 respectively. Further, means with different superscripts are significantly different from each other as indicated by scheffe post hoc test $(\alpha=0.5)$. Scheffe post hoc test revealed that respondents belonging to supermarket had highest motivation and respondents belonging to shopping mall and specialty 
chain were least and respondents belonging to hypermarket, discount world, departmental store, convenience store, branded outlet, category killer and etailing were inbetween.

- SSCM: One way anova reveals significant difference in SSCM between respondents belonging to different formats, where ' $\mathrm{f}$ ' value of 4.74 is found to be significant at .000 level. The mean score for respondents belonging to hypermarket, supermarket, shopping mall, discount world, departmental store, specialty chain, convenience store, branded outlet, category killer and e-tailing were 84.34, 84.51, 79.43, 76.80, 79.26, 74.00, 77.20, $81.43,78.00$ and 85.66 respectively. Further, means with different superscripts are significantly different from each other as indicated by scheffe post hoc test $(\alpha=0.5)$. Scheffe post hoc test revealed that respondents belonging to e-tailing had highest motivation and respondents belonging to hypermarket, supermarket and specialty chain were least and respondents belonging to shopping mall, discount world, departmental store, convenience store, branded outlet and category killer were inbetween.

- WRFM: One way anova reveals significant difference in WRFM between respondents belonging to different formats, where ' $\mathrm{f}$ ' value of 5.05 is found to be significant at .000 level. The mean score for respondents belonging to hypermarket, supermarket, shopping mall, discount world, departmental store, specialty chain, convenience store, branded outlet, category killer and etailing were $69.83,61.66,52.74,69.71$, $67.88,59.03,66.17,65.14,64.40$ and
72.80 respectively. Further, means with different superscripts are significantly different from each other as indicated by scheffe post hoc test $(\alpha=0.5)$. Scheffe post hoc test revealed that respondents belonging to e-tailing had highest motivation and respondents belonging to hypermarket, shopping mall and discount world were least and respondents belonging to supermarket, departmental store, convenience store, specialty chain, branded outlet and category killer were inbetween.

- RR: One way anova reveals significant difference in RR between respondents belonging to different formats, where ' $\mathrm{f}$ ' value of 7.40 is found to be significant at .000 level. The mean score for respondents belonging to hypermarket, supermarket, shopping mall, discount world, departmental store, specialty chain, convenience store, branded outlet, category killer and e-tailing were 84.36, 79.07, 70.64, 79.28, 81.86, 68.14, 80.93, $77.50,74.21$ and 81.14, respectively. Further, means with different superscripts are significantly different from each other as indicated by scheffe post hoc test $(\alpha=0.5)$. Scheffe post hoc test revealed that respondents belonging to hypermarket had highest motivation and respondents belonging to departmental store and specialty chain were least and respondents belonging to supermarket, discount world, shopping mall, convenience store, branded outlet, category killer and e-tailing were inbetween.

- WCEM: One way anova reveals significant difference WCEM between respondents belonging to different formats, where ' $\mathrm{f}$ ' value of 4.15 is found 
to be significant at .000 level. The mean score for respondents belonging to hypermarket, supermarket, shopping mall, discount world, departmental store, specialty chain, convenience store, branded outlet, category killer and etailing were $87.19,85.05,75.24,76.67$, $79.81,80.77,81.71,78.90,79.67$ and 82.29 respectively. Further, means with different superscripts are significantly different from each other as indicated by scheffe post hoc test $(\alpha=0.5)$. Scheffe post hoc test revealed that respondents belonging to hypermarket had highest motivation and respondents belonging to shopping mall and discount world were least and respondents belonging to supermarket, departmental store, specialty chain, convenience store, branded outlet, category killer and e-tailing were inbetween.

- CCPAM: One way anova reveals significant difference in CCPAM between respondents belonging to different formats, where ' $\mathrm{f}$ ' value of 5.77 is found to be significant at .000 level. The mean score for respondents belonging to hypermarket, supermarket, shopping mall, discount world, departmental store, specialty chain, convenience store, branded outlet, category killer and etailing were $86.17,81.60,72.11,78.46$, 83.48, 72.97, 75.26, 77.37, 73.66 and 78.29 respectively. Further, means with different superscripts are significantly different from each other as indicated by scheffe post hoc test $(\alpha=0.5)$. Scheffe post hoc test revealed that respondents belonging to hypermarket had highest motivation and respondents belonging to shopping mall, category killer and specialty chain were least and respondents belonging to supermarket, discount world, departmental store, convenience store, branded outlet and e-tailing were inbetween.

- WPM: One way anova reveals significant difference in WPM between respondents belonging to different formats, where ' $\mathrm{f}$ ' value of 4.63 is found to be significant at .000 level. The mean score for respondents belonging to hypermarket, supermarket, shopping mall, discount world, departmental store, specialty chain, convenience store, branded outlet, category killer and e-tailing were 81.71, $75.57,64.14,70.57,75.50,67.71,69.64$, $74.00,75.71$ and 76.57 respectively. Further, means with different superscripts are significantly different from each other as indicated by scheffe post hoc test $(\alpha=0.5)$. Scheffe post hoc test revealed that respondents belonging to hypermarket had highest motivation and respondents belonging to shopping mall and specialty chain were least and respondents belonging to supermarket, discount world, departmental store, convenience store, branded outlet, category killer and etailing were inbetween.

- OC: One way anova reveals significant difference in OC between respondents belonging to different formats, where ' $\mathrm{f}$ ' value of 3.94 is found to be significant at .000 level. The mean score for respondents belonging to hypermarket, supermarket, shopping mall, discount world, departmental store, specialty chain, convenience store, branded outlet, category killer and e-tailing were 84.29, 82.36, 71.71, 76.86, 78.57, 77.57, 82.50, 
$78.78,77.71$ and 80.71 respectively. Further, means with different superscripts are significantly different from each other as indicated by scheffe post hoc test $(\alpha=0.5)$. Scheffe post hoc test revealed that respondents belonging to hypermarket had highest motivation and respondents belonging to shopping mall, supermarket and convenience store were least and respondents belonging to discount world, departmental store, specialty chain, branded outlet, category killer and e-tailing were inbetween.

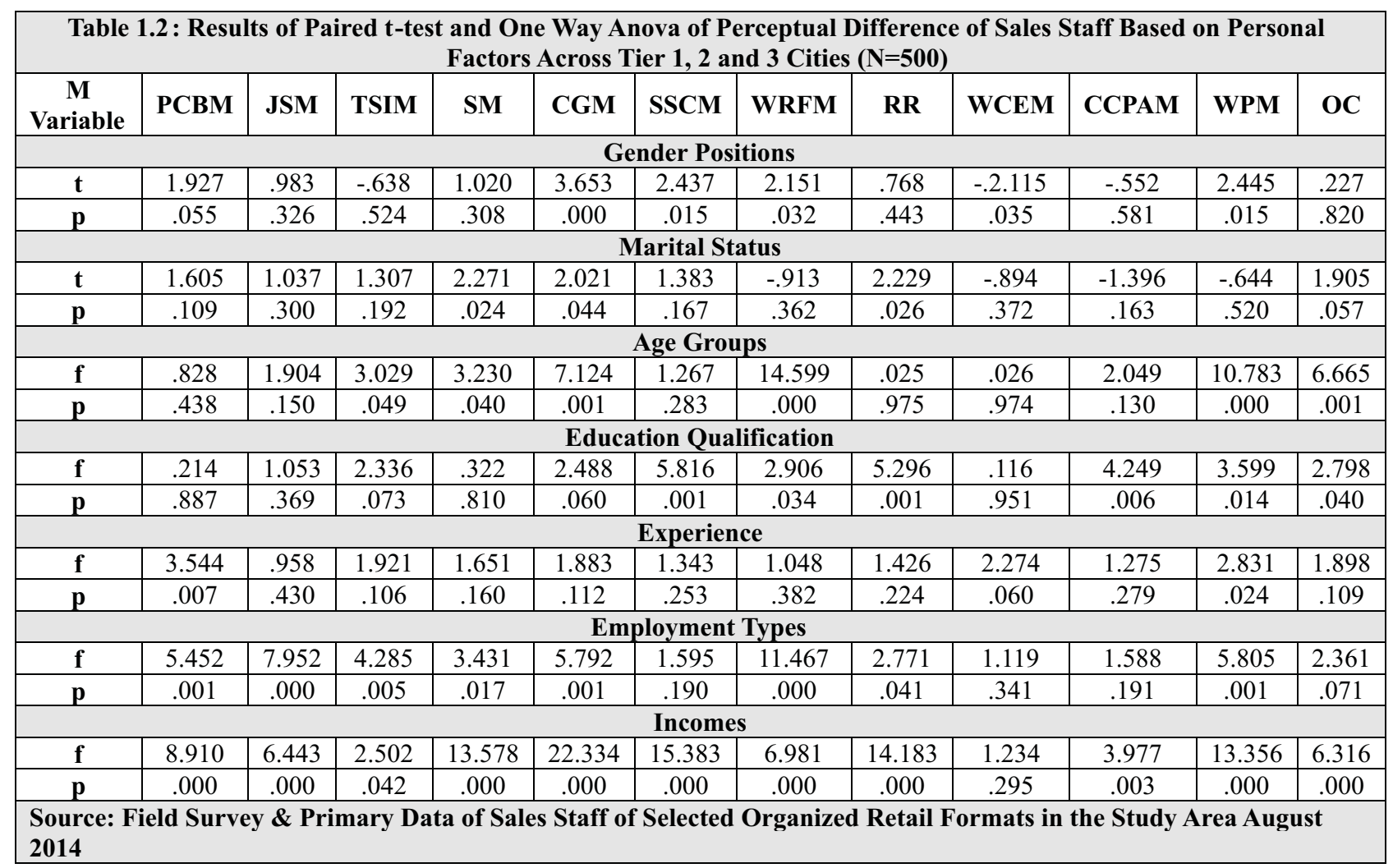

\begin{tabular}{|c|c|c|c|c|c|c|c|c|c|c|c|c|c|}
\hline \multicolumn{2}{|c|}{$\begin{array}{c}\text { Format/M } \\
\text { Variable }\end{array}$} & РCBM & JSM & TSIM & SM & CGM & SSCM & WRFM & $\mathbf{R R}$ & WCEM & ССРАМ & WPM & OC \\
\hline $\begin{array}{l}\text { HM } \\
\text { SM } \\
\text { SM } \\
\text { DW } \\
\text { DM }\end{array}$ & $\mathbf{f}$ & 2.742 & 2.850 & 3.680 & 3.431 & 2.521 & 4.738 & 5.051 & 7.404 & 4.149 & 5.771 & 4.632 & 3.936 \\
\hline $\begin{array}{l}\text { SC } \\
\text { CS } \\
\text { BO } \\
\text { CK } \\
\text { ET }\end{array}$ & $\mathbf{p}$ & .004 & .003 & .000 & .000 & .008 & .000 & .000 & .000 & .000 & .000 & .000 & .000 \\
\hline $\begin{array}{l}\text { HM: Hyp } \\
\text { Convenie } \\
\text { Source: } \\
\mathbf{2 0 1 4}\end{array}$ & Fiel & $\begin{array}{l}\text { arket, SN } \\
\text { store, BC } \\
\text { d Survey }\end{array}$ & $\begin{array}{l}\text { 1: Super } \\
\text { ): Branc } \\
\text { and Pr }\end{array}$ & $\begin{array}{l}\text { market, } \\
\text { ed outle } \\
\text { mary D }\end{array}$ & $\begin{array}{l}\text { A: Sho } \\
\text { CK: Ca } \\
\text { a of } \mathrm{Sa}\end{array}$ & $\begin{array}{l}\text { ing mal } \\
\text { gory kil } \\
\text { Staff }\end{array}$ & $\begin{array}{l}\text { DW: D } \\
\text {, ET: I } \\
\text { Select }\end{array}$ & $\begin{array}{l}\text { ount wo } \\
\text { ailing } \\
\text { Organiz }\end{array}$ & $\begin{array}{l}\text { DM: } \\
\text { R etai }\end{array}$ & $\begin{array}{l}\text { partmen } \\
\text { ormats }\end{array}$ & $\begin{array}{l}\text { l, } \mathrm{SC}: \mathrm{Sp} \\
\text { the Stud }\end{array}$ & $\begin{array}{l}\text { ialty ch } \\
\text { Area }\end{array}$ & $\begin{array}{l}\mathrm{n}, \mathrm{CS}: \\
\text { ugust }\end{array}$ \\
\hline
\end{tabular}




\section{Respondents Recommendation on Factors Influencing Motivation Across Formats}

1. The results of paired t-test and one way ANOVA of perceptual difference of sales staff gender, marital, age, education, experience, employment and income wise towards motivational factors across tiers has significant difference in the opinions towards the variables. So the formats should try to make an effort in the areas of motivation so as to improve perceptual difference towards motivation.

2. It has been observed that there is good deal of significant difference and least motivation across formats with the motivation variables like pcbm, jsm, tsim, sm, cgm, sscm, wrfm, rr, wcem, ccpam, wpm and oc. Therefore, measures have to be taken for these variables to increase sales staff productivity and to reduce the attrition of sales staff.

\section{Other General Suggestions and Recommendations}

- Retail jobs in the frontline are near minimum wage jobs and offer much lower compensation. Thus, improving on strong compensation system like bonus, PF, ESI, gratuity etc is suggested.

- Retail jobs are physically demanding. Sales staff is required to stand 10 hours a day, six days a week, work on weekends, holidays, festive days and moreover function throughout the year. Hence working hours, flexi working hours and time off to participate in community service is suggested.

- Lack of career growth prospects has been one of the major reasons for attrition in the retail sector. Retail jobs are also not career builders in the short run. Not many sales staff can grow to become store managers and there is limited scope. Thus modeling a career path can serve as an effective tool to retain sales staff as it provides them an opportunity to strive to reach higher levels in the formats and working high profile jobs/desirable locations is suggested.

- Things such as paying salaries on time, processing leave, loan and other requests on time, providing neat and clean changing rooms, good uniforms and most important, ensuring that their issues and grievances are redressed quickly is suggested.

- Retail sales staff face a lot of excessive or abusive criticism, dissension; opposition from customers all the time. They constantly need to be told that they are doing a good job, that their efforts are being noticed is suggested.

- Job rotation, job enlargement and job enrichment can act as a tool to prevent monotony thus enhances sales staff motivation and give more scope for creativity, to learn new things, or experiment with new ideas and use creative brain storming sessions is suggested.

- Solicit views/ideas from the sales staff to resolve the formats problems and improve upon the formats effectiveness and leadership qualities. An idea of opening staff club is also suggested.

- Much retail formats lack adequate facilities for sales staff, such as restrooms to relax, and pick up and drop services for employees working late, format subsidized child care. Considering this is suggested.

- Considering retail formats employ large number of women. Women sales staff should be motivated and that too married women must be encouraged and promoted 
for higher responsibilities. Revision of pay scale and perks for females is suggested.

- Appreciating and rewarding the best performing sales staff act as great motivation tools to retain sales staff. Thus make the most of nonfinancial motivators realistic like; promotions, recognition, rewards, praise etc is suggested.

- The formats can appreciate the sales staff publicly as and when he or she exhibits commendable performance. This has induction effect on the sales staff and they get motivated to perform better too is suggested.

- Apart from the peculiar work pattern, retail sales staff experience anxiety and stress on account of shortage of manpower, work overload, time pressures, deadlines and job insecurity. Discover new ways of fun at formats to keep sales staff relaxed is suggested.

- Since most of the sales staff feels, the retail sector is an opportunity and experience for future career, more training and enhancing knowledge is suggested.

- A number of business schools have come with special courses and degree in retail management so can suggest sales staff to get update and reimbursement for continuing education coursework is suggested.

- Develop the skills of sales staff by organizing career development programmes, personality development programme, work life balance, communication skills etc is suggested.

- Always open to support and listen to their ideas and concern and believe in open door policy and provide the sales staff with the opportunities/platforms to talk informally too is suggested.

- It is suggested that some supervisors or managers can personally go to the seat of each sale staff to ensure that the sales staff is performing his or her duties happily. This kind of caring attitude develops a sense of belonging in the sales staff is suggested.

- Greet the sales staff on the special days as birthdays, anniversaries and celebrate by sending SMS, e-mails, bunch of flowers, clapping hands and cutting cakes etc is suggested.

- Periodic surprises for a job well done, verbal or written recognition and photo within office to recognize employee of month is suggested.

- It is suggested that the supervisors and managers of formats can present themselves as role model by being honest, punctual and disciplined at work. Also suggested to the supervisors and managers that coming to office timely and avoiding unethical practices at work can also motivate the sales staff.

- The families of sales staff can be invited in the cultural programmes/events organized by the formats is suggested.

- $\quad$ Provide the sales staff with an encouraging work culture, which inspires them to perform satisfactorily, is suggested.

- Background music is a tool to boost sales staff motivation in formats is suggested.

- Formats design and interiors also motivates sales staff, so is suggested to focus.

- The sales staff achievements can be shared through an in-house magazine is suggested. 
- Managers and supervisors can make it a point to personally visit if the sales staff or his or her dependent gets unwell and admitted in the hospital is suggested.

- It is suggested that the managers and supervisors can attend the social functions organized by the sales staff and share the joy. This develops a sense of belongingness in the sales staff and others.

- The formats can recognize the children of the sales staff on achieving excellence in academics, games and sports, competitive examinations etc. is suggested.

- It is suggested that the formats can offer watches, diaries, calendars, tiepins, wallets, $t$-shirt etc to the sales staff at time of occasion, some of the sampled formats offer free lunch, coffee breaks and dinner with managers and supervisors.

- The sales staff can be rewarded with trophies, plaques, citations, scrolls, letter of appreciation is suggested.

- Reward good performances with extra perks, like concert tickets, gift coupons, vouchers, paid holidays, insurance covers, movie tickets, vacation trips, coupon redeemable at stores, early time off, anniversary, dating and birthday presents and so on is suggested.

- It is suggested that the formats can celebrate success by cheering up with the sales staff. Such kind of celebrations can be organized at various levels. This develops team spirit in the group members and motivates them to perform in synchronized manner.

- Finally last but not the least effective planning enhances sales staff motivation.

\section{Conclusion}

The challenge of motivation of sales staff in organized retail is not peculiar to formats in tier 1, 2 and 3 cities in Karnataka alone and in fact, the problem is more accentuated in case of the developed and developing nations like the US, UK and India. A number of industry players have realized that in order to come out of the vicious circle of human resource challenges the crux of the problem i.e. motivation of sales staff, need to be tackled with the weapon of trend motivation techniques i.e. beyond monetary compensation.

\section{References}

1. Anjali Prayag and Sandeep Kulhalli, (Feb. 23 2010), Business Head, Retailing Services Group, Titan's Initiative to Motivate Sales Staff, Bangalore.

2. Michael Kilger and Stefen Tweraser, (2005), Motivating Retail Employees for Top Performance and Productivity.

3. Rickey Casey and Jay Robbins, (2005), Motivating Front Line Staff for Bottom Line Results.

4. William J Rothwell, (May 2006), Motivating for Retention: Motivating is a Topic of Perennial Interest, HRM Review.

5. Susan Abraham and A. Kumudha, (AprilJune 2007), HR Challenges in Retailing in India, Personal Today.

6. Nityanand Rao $\mathrm{S}$ and Sharvani Bavirishetty, (June 2008), Attrition in the Indian Retail Sector, HRM Review.

7. Reena Shah and Pooja D Kunwar (June 2010), HR Dilemmas in the Indian Retail Sector, HRM Review.

8. Waraporn Kongnawang, (2010), Factors Influencing Employee Motivation in Retailing Stores, RU. Int. J. Vol.4 (2). 
9. Tan Teck-Hong and Amna Waheed, ( jan 2011), Herzberg's Motivation-Hygiene Theory and Job Satisfaction in the Malaysian Retail Sector: The Mediating Effect of Love of Money, paper No: 30419, Vol. 16, No. 1, 73-94, Asian Academy of Management Journal.

10. Debasis Bhattacharya and Subrata Ray, (August 2011), Motivating Retail Sales Personnel Customer Orientations: An Empirical Study, Indian Journal of Marketing.

11. Mosammod Mahamuda Parvin and M M Nurul Kabir, (December 2011), Factors Affecting Eemployee Job Satisfaction of Pharmaceutical Sector, Vol.1 No.9 [113123], Australian Journal of Business and Management Research.

12. Thomas Steenburgh and Michael Ahearne, (July 2012), Motivating Salespeople: What Really Works, ISSUE HBR.

13. Shyam B R and N K Ramachandra Gowda, (April 2013), Motivating Sales Staff in the Big Box Retail - An Indelible Challenge: Published as edited book - FDI Issues in Indian Retail Sector, Article No: 27, Page No: 144 - 146, Himalaya Publishing House Pvt. Ltd. (ISBN: 97893-5097-471-1)
14. Shyam B R and N K Ramachandra Gowda, (Sep 28th 2013), A Descriptive Study Of Motivating Sales Staff Towards Selected Organized Retail Formats With Special Reference To Mysore City, Karnataka: Article No: 1, Vol 4, Issue 3, Page No 01-06. International Journal of Communications and Engineering (IJCAE), (ISSN: 0988-0382E).

15. Martha Harunavamwe and Herbert Kanengoni, (14th October 2013), The Impact of Monetary and Non-Monetary Rewards on Motivation among Lower Level Employees in Selected Retail Shops, Vol. 7(38), pp. 3929-3935, African Journal of Business Management.

16. Teoh Teik Toe, Werner R. Murhadi and Wang Lin, Research Study on the Correlation Between Employee Job Satisfaction and Employee Motivation, James Cook University AustraliaSingapore Campus, University Surabaya, Indonesia, Anglia Ruskin University, UK.

17. Tesco, Motivational theory in practice at Tesco, www.tesco.com. 